\title{
Actual Practices of Environmental Performance in Malaysia's Hotel Industry: Comparison among Malaysia, Mexico and Turkey Hotel Industry
}

\author{
Yusmani Mohd Yusoff*
}

School of Business Management, College of Business, Universiti Utara Malaysia, 06010, Sintok Kedah, Malaysia

*Corresponding author: yusmani@uum.edu.my

Article history: Received 25 February 2019 Received in revised form: 05 April 2019 Accepted: 28 May 2019 Published online: 29 August 2019

\begin{abstract}
Environmental performance generally led to various benefits for example cost savings, regulatory compliance, increase image and competitiveness. Along with the movement of environmental concerns, the hotel industry also continuously put an interest in environmental performance programs. The adoption of environmental performance programs in Malaysia's hotel industry is not widespread regardless of the success of several international hotel groups. Therefore, it is important to identify the environmental performance programs in the hotel industry by providing fresh insights and empirical evidence of the actual environmental performance programs that have been practicing in Malaysia. This study involved the participation of 206 respondents. The main finding is the environmental performance programs in Malaysia's hotel industry can be classified as four categories: energy saving, green sourcing, resource conservation, and water management and conservation. This result indicates that in Malaysia, the hotel industry performs four types of environmental performance programs and other countries such as Mexico and Turkey also carry out the same environmental performance activities as implemented in Malaysia.
\end{abstract}

Keywords: Environmental Performance, Hotel Industry, Malaysia, Mexico, Turkey

\begin{abstract}
Abstrak
Prestasi alam sekitar secara umumnya membawa kepada pelbagai faedah contohnya penjimatan kos, pematuhan peraturan, meningkatkan imej dan daya saing. Seiring dengan pergerakan terhadap kebimbangan alam sekitar, industri hotel juga terus menaruh minat terhadap program-program prestasi alam sekitar. Amalan program prestasi alam sekitar di industri hotel Malaysia tidak dipraktikkan dengan meluas tanpa mengambil kira kejayaan beberapa kumpulan hotel antarabangsa. Oleh itu, adalah penting untuk mengenal pasti program-program prestasi alam sekitar di industri hotel dengan memberikan pandangan baru dan bukti empirikal mengenai program-program prestasi alam sekitar sebenar yang telah diamalkan di Malaysia. Kajian ini melibatkan penyertaan 206 responden. Hasil penemuan utama adalah program prestasi alam sekitar di industri hotel Malaysia boleh dikelaskan sebagai empat kategori; penjimatan tenaga, sumber hijau, pemuliharaan sumber dan pengurusan air dan pemuliharaan. Hasilnya menunjukkan bahawa di Malaysia, industri hotel melaksakan empat jenis program prestasi alam sekitar dan negara-negara lain seperti Mexico dan Turki juga melaksanakan aktiviti-aktiviti prestasi alam sekitar seperti yang dilaksanakan di Malaysia.
\end{abstract}

Kata kunci: Prestasi alam sekitar, industri hotel, Malaysia , Mexico, Turkey

() 2019 Penerbit UTM Press. All rights reserved

\subsection{INTRODUCTION}

The concerns of the business activities' effects on the environment have increased since the 1980s in Western countries (Gadenne, Kennedy, \& McKeiver, 2009). Various stakeholders, for example, employees, customers, suppliers, and local communities have shown their concerns towards the environmental issues contributed by businesses. This has led organizations in the contemporary era facing significant environmental pressure (from the shareholders and the government, customers, suppliers, and other stakeholders) to commit to environmental performance (Daily, Bishop, \& Massoud, 2012). Since 1990, various organizations started to enhance their environmental performance programs (Wong, Tan, $\mathrm{Ng} \&$ Fong, 2013) due to the benefits gained from these programs such as to get a competitive advantage among the competitors (Chan, 2008).

There is an increasing number of studies that investigate how to improve the environmental performance of the organizations with various of the studies were focused on the manufacturing industry such as studies by Jabbour, Santos, and Nagano (2008), Williamson, Lynch-Wood and Ramsay (2006), Yusoff, Othman, Fernando and Amran (2015). AlKhidir and Zailani (2009) found that there are two major environmental problems caused by manufacturing industry in Malaysia, hazardous and solid wastes and atmospheric pollution. However, the hotel industry also contribute to the massive issues of the environment as hotel industry contributes to three main areas of environmental issues: water, energy, and waste (Graci \& Kuehnel, 2011). Along with this general trend of environmental concerns, the hotel industry has directed a continually increasing interest in environmental performance programs (Kang, Lee, \& Huh, 2010). 
Yusof and Jamaludin (2013) pointed out that in the hotel industry, environmental performance programs have grown into a significant issue due to the response to the increasing concern for sustainable hotel industry services. There is an increased pressure on the owner/manager of the hotel industry to improve its environmental performance programs and activities (de Grosbois, 2012). This is because the hotel industry consists of various size of individual hotels and the overall impact of these individual hotels will contribute to a more significant effect on the local environment. However, in Malaysia, the knowledge about environmental issues is still scant (Kasim, 2004). Organizations in the hotel industry that can manage, measure and communicate the environmental performance, would get a better image among society as it plays a critical role in buying behavior (Lee, Hsu, Han, \& Kim, 2010).

Hence, to enhance environmental performance in the hotel industry, it is important to recognize the environmental performance programs in the hotel industry by providing fresh insights and empirical evidence of the actual environmental performance programs that have been practicing primarily in Malaysia. Therefore, this study explores the actual practices of environmental performance programs in Malaysia's hotel industry and make a comparison with the practices of environmental performance programs in Mexico and Turkey as these two countries have been implementing environmental performance programs in their hotel industry extensively.

\subsection{LITERATURE REVIEW}

\section{Environmental Performance}

Recently, the number of organisational sociologists conducted research on the environmental issues has been increasing (Hoffman, 2004; Bansal \& Gao, 2006; Jermier, 2008) due to the importance of the environmental performance as one of the sustainable factors for contemporary organizations especially in hotel industry (Rao, la O' Castillo, Intal, \& Sajid, 2006). In 2012, Daily et al. argued that various stakeholders such as creditors, investors, shareholders, consumers, employees, and the public keep put pressure on the organization's environmental performance. Environmental performance generally emphasizes on the consequences of corporate activities linked to the natural environment (Trumpp, Endrikat, Zopf \& Guenther, 2015). Additionally, environmental performance becomes a benchmark of the level of organizational success when it involved in executing environmental performance programs to reduce the harmful impact of its business activities on the natural environment. Thus, the commitment and efforts towards environmental concerns have been seen over the output of environmental performance (Gadenne et al., 2009).

According to Sutantoputra, Lindorff, and Johnson, (2012), environmental performance consists an extensive range of areas such as the existence of environmental management systems, emissions to air, waste management, and land and water. Environmental performance is commonly recognized as a measure of an "organization's impacts on living and non-living natural systems, including ecosystems, land, air, and water" (GRI 2002, p. 48). Also, environmental performance generally emphasizes the consequences of corporate activities linked to the natural environment (Trumpp et al., 2015)

\section{Environmental Performance Assessment, Metrics, Indicators and Levels}

Organizations established a variety of yardsticks or measurements that comprise of numerous basics of environmental performance (Ilinitch, Soderstrom, \&Thomas, 1998) due to meeting the rapid response for environmental performance awareness among the stakeholders. For instance, numerous measurement systems were introduced for example environmental rating metrics, corporate environmental scorecard, and corporate environmental reports by the organizations (Ilinitch et al., 1998). According to Srebotnjak (2007), there are various environmental performance assessment such as assessing the outcomes of a system from a viewpoint centered on diminishing the effect of environmental issues over establishing and improving guidelines and procedures that look for the improvement of the relationships between traditional objectives and sustainability. Furthermore, Milliman \& Clair (1996) found there are several approaches that can be used to measure environmental performance such as adopting corporate-wide metrics for determining resource acquisition, usage and waste; performing information systems to track resource activities and conducting field audits to offered opportunities for employees to recognize problems while gaining information and response about the environmental performance of the organization. Besides, environmental performance metrics involve eco-efficiency improvement, lean practices, and reduction of carbon footprint (Subramanian, Abdulrahman, Wu \& Nath, 2015).

Environmental performance can be measured by a set of indicators for instance low environmental emissions, pollution prevention, waste minimization and recycling activities (Lober, 1996). Indicators are essential as management tools solve environmental issues because indicators keep track of the progress, bring a description of trends and changes happened and evaluate the effectiveness of policies executed (Puig, Wooldridge, \& Darbra, 2014). According to United Nations (1997), an Environmental Performance Indicator (EPI) is defined as "an information tool that summarises data on complex environmental issues to show overall status and trends of those issues". While according to ISO 14031: Environmental Performance Evaluation (ISO, 1999), Environmental Performance Indicators has three categories; firstly, is Management Performance Indicators (MPIs), refers to "provide information about the management efforts that influence the environmental performance of the port". Secondly, is Operational Performance Indicators (OPIs) is about "provide information about the environmental performance of the port's operations". Lastly is Environmental Condition Indicators (ECIs) refers as "provide information about the condition of the environment'. EPIs in environmental issues concern on the impacts of organization activities on non-living and living, as well as air, soil, water and ecosystems (Dantes, 2003).

On the other hand, Delmas and Blass (2010) have divided environmental performance levels into three main categories; firstly, is the environmental impact that consists usage of energy, emissions, plant accidents, toxicity and outcomes of these accidents. Secondly, is regulatory compliance that involves lawsuits regarding improper disposal of hazardous waste, penalties for its' clean up and mandatory installation of recycling and treatment plant. Thirdly is organization process that involves enhancement in environmental management systems, expenses in pollution control technology and organization procedures while Mendelson and Piasecki (1999) stated that environmental performance could be measured from three levels; reduction in environment, health and safety risk; reduction in legal responsibility; and finding a potential approach in terms of environmental protection to gain competitive advantage. 
In addition, many research use proxies for environmental performance (Bansal \& Gao, 2006). However, some environmental performance proxies use the actual dimensions of the material input or output such as waste processing activities, reports of toxic emissions and waste generation (King \& Lenox, 2000). Other than using actual dimensions, there are some proxies of environmental performance, which are output from some organizations which are trying to meet society's expectations improvement approach related to the environmental issues, but it is not trying to measure tangible results (Gadenne et al., 2009). As an example, an organization's environmental performance has been measured through the adoption of ISO 14001 (environmental management system) and the number of lawsuits faced by an organization (Winn \& Angell, 2000; Jiang \& Bansal, 2003). Additionally, Judge and Douglas (1998) measured the environmental performance by the effectiveness of organizations to meet and exceed the expectations of society concerning environmental concerns.

\section{Environmental Performance in Hotel Industry}

In the hotel industry, the environmental performance programs involved are energy consumption management, water management and oil recycling (Alcaraz, Susaeta, Suarez, Colon, Gutierrez, Cunha, Idrovo, Weisz, Correia, \& Pin, 2015). Based on the study by Siti-Nabiha, George, Wahid, Amran, Abustan and Mahadi (2011) they found several environmental performance programs that were common among a majority of the hotels such as most of the hotels educated and trained their employees to be eco-friendly at a certain level, for instance, to turn off the whole unnecessary devices when not in use, save water and energy while minimizing waste. Furthermore, the hotels also recycled their grey water, used energy efficient devices, for example, light bulbs in public areas and used key cards to decrease electricity bills. Most of the hotels also managed and separated their solid and liquid waste by specialized equipment, and they implement the recycling and reusing programs by educating their employees the proper ways to practice recycling and waste sorting. Additionally, a study by Yusof and Jamaludin (2013) found that all the hotels in their research implementing the environmental performance programs that related to reducing the waste, water, and energy by conducting the monthly review of their environmental performance programs. The findings from this study also point out; the hotels practice the environmental training for their employees during the orientation day and regular basis.

Most of the hotel industry chain has a corporate environmental policy whereby they provide their policies to develop and implement environmental initiatives. Therefore, the hotel industry needs to commence practices that help to achieve the environment sustainability (Samdin, Bakori, \& Hassan, 2012) such as environmental performance programs. With the increasing inquiry on hotels' environmental impacts has been met with a rising communication effort by large hotels about their environmental performance programs and these efforts can be seen through a growing number of reports especially on websites and corporate reports (Kasim, 2009). A further point as mentioned by Chan (2008), the execution of environmental performance programs by hotel industry would support the industry to cut the operating cost of hotel activities and also will allow hotels to increase their reputation and protect the environment.

Table 1 depicts the hotel environmental performance programs in Mexico and Turkey. As we can see, there are similar environmental performance programs in these countries such as conserving energy, water saving and recycling food or kitchen garbage. Malaysia's hotel industry began to identify environmental performance programs that can help them to overcome problems related to environmental issues due to the deepening environmental issues caused by the activities of the hotel industry (Siti-Nabiha et al., 2011). However, in Malaysia, the adoption of environmental performance programs primarily in the hotel industry is not widespread (Yusof \& Jamaludin, 2013), therefore, this study is attempts to examine what are the actual environmental performance programs in Malaysia's hotel industry as the implementation of environmental performance programs in the Malaysia's hotel industry were still insignificant in line with unattractive gains compared to costs, insufficient incentives or allowance from the government to embolden the execution of green practices and deficiency of knowledge about the diversity of approaches that can be used to manage and protect the environment (SitiNabiha et al., 2011). This study explores the actual practices of environmental performance programs in Malaysia's hotel industry and make a comparison with the practices of environmental performance programs in Mexico and Turkey as these two countries have been implementing environmental performance programs in their hotel industry extensively (Revilla, Dodd \& Hoover ,2001; Erdorgan \& Baris, 2007). 
Table 1 Hotel environmental performance programs in Mexico and Turkey

\begin{tabular}{|c|c|}
\hline Hotel Environmental Performance Programs in Mexico & Hotel Environmental Performance Programs in Turkey \\
\hline \multirow{27}{*}{$\begin{array}{l}\text { Conserving energy } \\
\text { Recycling back-of-the-house paper } \\
\text { Recycling kitchen garbage } \\
\text { Using biodegradable products } \\
\text { Using automatic faucets } \\
\text { Water savings } \\
\text { Use efficient lights } \\
\text { Hazardous waste reduction and health issues } \\
\text { Control hazardous residues } \\
\text { Use bacterium in the residual water } \\
\text { Use organic food } \\
\text { Install a residual water plant } \\
\text { Use low flow showers in guest rooms } \\
\text { Use automatic showers for employees } \\
\text { Recycling and resources reduction }\end{array}$} & Nature of Waste Management \\
\hline & Separate collection of hazardous waste \\
\hline & Recovery of used cooking oil \\
\hline & Recovery of food waste \\
\hline & Composting of organic and food waste \\
\hline & Knowledge of the existence of recycling firms \\
\hline & Knowledge of recycling firms \\
\hline & A basis for Purchasing Activities \\
\hline & Cooperation with recycling firms \\
\hline & Paying attention to recyclable materials \\
\hline & Purchasing single-use materials \\
\hline & Encouraging seller firms for recycling \\
\hline & Purchasing from local firms \\
\hline & Purchasing energy-saving materials \\
\hline & Purchasing less-hazardous cleansers \\
\hline & Nature of Energy Use and Resource Conservation \\
\hline & Wastewater treatment \\
\hline & Discharge of treated wastewater to the environment \\
\hline & Use of treated wastewater in garden irrigation \\
\hline & Energy saver control system in guest rooms \\
\hline & A key-card control system in guest rooms \\
\hline & Using energy-saving light bulbs in guest rooms \\
\hline & Use of solar energy \\
\hline & Considering guest requests for linen or towel changes \\
\hline & Using photocell lighting in general restrooms \\
\hline & Sorting linen according to dirtiness \\
\hline & Deciding on the number of cleansers to use \\
\hline
\end{tabular}

Source: Revilla et al. (2001) and Erdogan and Baris (2007)

\subsection{METHODOLOGY}

Population and Sample

206 hotels in Malaysia have been involved in this study. This study only focused on 3, 4 and 5-star as 1 and 2-star hotels showed less demonstration in adopting environmental performance programs (Rodríguez-Antón, del Mar Alonso-Almeida, Celemín, \& Rubio, 2012). In Malaysia, based on the statistics provided by the Ministry of Tourism and Culture Malaysia, the total number of 3, 4 and 5-star hotels registered is 721 hotels (April 2016) as stated in Table 2. This study distributed a total of 250 questionnaires to target respondents. Out of 250 , only 225 were returned, and 206 questionnaires usable represented 82 percent of the response rate.

Table 2 Total number of hotels in Malaysia based on star

\begin{tabular}{ll}
\hline Type of Hotel & Number of Hotel \\
\hline 3-star & 475 hotels $(65.88$ percent) \\
4-star & 147 hotels (20.39 percent) \\
5-star & 99 hotels (13.73 percent) \\
Total Number of 3, 4 and 5-star hotels in Malaysia up to April 2016. & 721 hotels \\
\hline
\end{tabular}

\section{Measurement}

This study adapted the items of the actual practices of environmental performance in Malaysia's hotel industry from a qualitative research by Yusof and Jamaludin (2013). The reliability of the items was measured using Cronbach alpha as these items are not statistically tested. The Cronbach's alpha reported for the overall items for this study is 0.817 . Each dimension of environmental performance was measured on a 5-point Likert scale, ranging from one (strongly disagree) to five (strongly agree). Moreover, the words "my hotel" was used for each respective item to fit the context of this study as proposed by expert opinions. The 18-measurements for environmental performance adapted from the original items as shown in Table 3. 
Table 3 Measurement items for environmental performance

\begin{tabular}{|c|c|}
\hline Original Items & Adapted Items \\
\hline 1. Use local products from the community. & 1. My hotel uses local products from the community. \\
\hline Buy products from the green vendor. & My hotel buys products from green vendors. \\
\hline Used green chemical products. & My hotel uses green chemical products. \\
\hline Sub-metering. & My hotel uses sub-metering. \\
\hline Waste separation program $3 \mathrm{R}$ & $\begin{array}{l}\text { My hotel implements waste separation program } 3 \mathrm{R} \text { (recycle, reuse and } \\
\text { reduce) }\end{array}$ \\
\hline Percentage of energy reduction. & My hotel implements energy reduction. \\
\hline Install occupancy-based room unit controllers. & My hotel installs occupancy-based room unit controllers. \\
\hline Air cond set to 23 to 24 degrees. & In my hotel, air cond set to 23 to 24 degrees. \\
\hline Regular maintenance of the air cond system. & My hotel practices regular maintenance of air cond system. \\
\hline Use of energy saving equipment in the office. & My hotel uses energy saving equipment in the office. \\
\hline Using LED lighting. & 11. My hotel uses LED lighting. \\
\hline Using energy saving bulbs. & My hotel uses energy saving bulbs. \\
\hline 13. Provide auto sensor-controlled lighting (dimmer). & 13. My hotel uses auto sensor-controlled lighting (dimmer). \\
\hline $\begin{array}{l}\text { 14. During the day and late night switch off lighting at } \\
\text { unusable space. }\end{array}$ & $\begin{array}{l}\text { 14. My hotel practices switch off lighting at unusable space during the day } \\
\text { and late at night. }\end{array}$ \\
\hline Low-flow toilets and showerheads. & My hotel uses low-flow toilets and showerheads. \\
\hline 16. Regularly check and repair the leak. & My hotel practices regular check and repair leak. \\
\hline 17. Encourage guests to re-use towels. & 17. My hotel encourages guests to re-use towels. \\
\hline 18. Encourage guests to save water. & My hotel encourages guests to save water. \\
\hline
\end{tabular}

Source: Yusof and Jamaludin (2013)

\subsection{ANALYSIS}

\section{Hotel's Profile}

Table 4 shows the profile of participating hotels in this study. Regarding a total number of the employees in the hotel, the majority falls below the range of 100 to 149 employees (63.1 percent), followed by below than 100 employees (29.1 percent) and 150 to 299 employees (7.8 percent). In terms of ISO 14001 EMS certification, most of the hotels do not have the certification (54.9 percent), while the rest of the hotels are certified to ISO 14001 EMS (45.1 percent).

Relating to hotel classification, the majority of hotels are 3-star (47.1 percent), followed by 4-star hotels (31.1 percent) and 5-star hotels (21.8 percent). Furthermore, regarding the type of hotel, the majority of hotels are international chain hotel (38.8 percent), followed by the non-chain hotels (33.0 percent) and local chain hotels ( 28.2 percent).

Table 4 Hotels' demographic profiles

\begin{tabular}{lll}
\hline Demographic Data & Frequency $(\mathbf{N = 2 0 6})$ & Percentage $(\%)$ \\
\hline Total Number of Employees & 60 & 29.1 \\
$<100$ & 130 & 63.1 \\
Between 100 and 149 & 16 & 7.8 \\
Between 150 and 299 & & \\
& 93 & 45.1 \\
ISO 14001 EMS Certification & 113 & 54.9 \\
Yes & & \\
No & 45 & 21.8 \\
Hotel Classification & 64 & 31.1 \\
5-star & 97 & 47.1 \\
4-star & & \\
3-star & 68 & 33.0 \\
Type of Hotel & 80 & 38.8 \\
Non-chain hotel & 58 & 28.2 \\
International chain hotel & & \\
A local chain hotel & & \\
&
\end{tabular}

\section{Exploratory Factor Analysis}

As the measurement items for this study were adapted from the qualitative research and had not been statistically tested. Therefore, this study carried out exploratory factor analysis to examine the reflection of items on a single variable. For running this type of test, there are two assumptions; the value of Kaiser-Meyer-Olkin's measure (KMO) should exceed 0.60 and Bartlett's test should be significant at 5 percent (Jabbar \& Abid, 2014). However, according to Williams, Onsman, and Brown (2010), the KMO index ranges from 0 to 1 , and 0.50 is considered appropriate for factor analysis.

Therefore, the KMO and Bartlett's test for each variable were inspected to assess the underlying dimensions of every construct as shown in Table 5. Four items were deleted after running the exploratory factor analysis three times due to extraction value below than 0.50 . The retained 14 items fell under four components and were renamed accordingly as stated in Table 6. 
Table 5 Exploratory factor analysis

\begin{tabular}{lll}
\hline Constructs & KMO Measure & Bartlett's Test \\
\hline Environmental Performance & 0.80 & 0.00 \\
\hline
\end{tabular}

Table 6 New components of environmental performance

\begin{tabular}{|c|c|c|c|}
\hline \multicolumn{2}{|c|}{ Components } & \multicolumn{2}{|l|}{ Items } \\
\hline 1. & Energy Saving & 1. & My hotel installs occupancy-based room unit controllers (EP 7) \\
\hline & & 2. & My hotel implements an energy reduction (EP 6) \\
\hline & & 3. & In my hotel, air con is set to 23 to 24 degrees (EP 8) \\
\hline & & 4. & My hotel implements waste separation program 3Rs (EP 5) \\
\hline & & 5 . & My hotel practices regular maintenance of air con system (EP 9) \\
\hline & & 6. & My hotel uses energy saving equipment in the office (EP 10) \\
\hline \multirow[t]{3}{*}{2.} & Green Sourcing & 1. & My hotel buys products from green vendors (EP 2) \\
\hline & & 2. & My hotel uses green chemical products (EP 3) \\
\hline & & 3. & My hotel uses local products from the community (EP 1) \\
\hline \multirow[t]{2}{*}{3.} & Resource Conservation & 1. & My hotel uses energy saving bulbs (EP 12) \\
\hline & & 2. & My hotel uses LED lighting (EP 11) \\
\hline \multirow[t]{3}{*}{4.} & Water Management and Conservation & 1. & My hotel encourages guests to re-use towels (EP 17) \\
\hline & & 2. & My hotel encourages guests to save water (EP 18) \\
\hline & & 3. & My hotel uses sub-metering (EP 4) \\
\hline
\end{tabular}

\subsection{RESULTS AND DISCUSSION}

The significant finding from this study is the environmental performance programs in Malaysia's hotel industry falls under four categories; energy saving, green sourcing, resource conservation, and water management and conservation. This result indicates that in Malaysia, hotel industry currently practices these four types of environmental performance programs and the items under all these four also similar to the environmental performance programs in the other countries such as Mexico and Turkey (see Table 7). In Mexico, a study by Revilla, Dodd, and Hoover (2001) on eight hotel corporation showed that they started to implement environmental performance programs in 1995 and their primary environmental performance programs implemented as stated in Table 7 . The results from this study showed that they implemented recycling kitchen garbage, using biodegradable products, water saving, and same with the hotel industry in Malaysia, the hotels also perform the same programs to enhance their environmental performance.

Furthermore, in Turkey, a study by Erdorgan and Baris (2007) was conducted to investigate the practices of waste management, energy use, and nature of environmental protection of hotels in Ankara, Turkey. This study found that these hotels have been implemented several environmental performance programs, as stated in Table 7. Environmental performance programs in Turkey fall classified under three main programs; nature of waste management, a basic for purchasing activities and nature of energy use and resource conservation. Compare with these two studies, we can see our environmental performance programs are more comprehensive, as hotels in Malaysia implementing specific programs according to specific areas such as for energy saving involves activities of installs occupancy-based room unit controllers, implements energy reduction, air con is set to 23 to 24 degrees, implements waste separation program 3 Rs. practices regular maintenance of air con system and uses energy saving equipment in the office.

Also, this result shows that the hotel industry in Malaysia is aware of the importance and benefits of environmental performance programs as 45.1 percent of the hotels have been certified with ISO 14001. Despite the previous study by Kasim (2009), she stated that there are several reasons that lead to this issue such as deficiency of awareness and information about the environmental issues, especially in Malaysia's hotel industry, the study showed that this industry was reluctant in adopting environmental performance programs in line with the lack of information and awareness relating to the environmental issues. The present study shows that the hotel industry in Malaysia started to implement environmental performance programs. In recent decades, organizations are required to reassess their roles in the conservation of natural resources along with increasing demand from various stakeholders and new environmental regulations. Therefore, environmental performance programs of the hotel industry in Malaysia will help them to gain a competitive advantage in the market (Fraj \& Matute, 2015).

Table 7 Comparison of hotel environmental performance programs among Mexico, Turkey, and Malaysia

\begin{tabular}{|c|c|c|}
\hline $\begin{array}{l}\text { Hotel Environmental Performance Programs } \\
\text { in Mexico }\end{array}$ & $\begin{array}{l}\text { Hotel Environmental Performance Programs } \\
\text { in Turkey }\end{array}$ & $\begin{array}{l}\text { Hotel Environmental Performance Programs } \\
\text { in Malaysia }\end{array}$ \\
\hline Conserving energy & Nature of Waste Management & Energy Saving \\
\hline Recycling back-of-the-house paper & Separate collection of hazardous waste & Installs occupancy-based room unit controllers \\
\hline Recycling kitchen garbage & Recovery of used cooking oil & Implements energy reduction \\
\hline Using biodegradable products & Recovery of food waste & Air con is set to 23 to 24 degrees \\
\hline Using automatic faucets & Composting of organic and food waste & Implements waste separation program 3Rs \\
\hline Water savings & Knowledge of the existence of recycling firms & Practices regular maintenance of air con system \\
\hline Use efficient lights & Knowledge of recycling firms & Uses energy saving equipment in the office \\
\hline Hazardous waste reduction and health issues & A basis for Purchasing Activities & Green Sourcing \\
\hline Control hazardous residues & Cooperation with recycling firms & Buys products from $\mathrm{g}$ \\
\hline Use bacterium in the residual water & cyclable materials & Uses green chemical prod \\
\hline Use organic food & Purchasing single-use materials & Uses local products from the community \\
\hline
\end{tabular}


Install a residual water plant Use low flow showers in guest rooms Use automatic showers for employees Recycling and resources reduction
Encouraging seller firms for recycling

Purchasing from local firms

Purchasing energy-saving materials

Purchasing less-hazardous cleansers

Nature of Energy Use and

Conservation

Wastewater treatment

Discharge of treated wastewater to the

environment

Use of treated wastewater in garden irrigation

Energy saver control system in guest rooms

A key-card control system in guest rooms

Using energy-saving light bulbs in guest rooms

Use of solar energy

Considering guest requests for linen or towel

changes

Using photocell lighting in general restrooms

Sorting linen according to dirtiness

Deciding on the number of cleansers to use

Source: Study by the author and Revilla et al. (2001) and Erdogan and Baris (2007)

\subsection{CONCLUSION}

This study provides essential recommendations for practitioners in Malaysia's hotel industry. Based on the results, it is clearly stated that in Malaysia, environmental performance programs can be categorized under four types; energy saving, green sourcing, resource conservation, and water management and conservation. Specifically, the results from this study can be used by policymakers to manage the environmental programs as the results providing actual environmental performance programs in the hotel industry. Other hotels in Malaysia can use these results to design their environmental performance programs and use these programs as a benchmark once strategize their environmental performance programs.

\section{References}

Alcaraz, J.M., Susaeta, L., Suarez, E., Colon, C., Gutierrez, I., Cunha, R., Idrovo, S., Weisz, N., Correia, M., \& Pin, J.R. (2015). The Human Resources Contribution To Social Responsibility And Environmental Sustainability: Explorations from Ibero-America.

AlKhidir, T., \& Zailani, S. (2009). Going Green In Supply Chain Towards Environmental Sustainability. Global Journal of Environmental Research, 3(3), $246-251$.

Bansal, P., \& Gao, J. (2006). Building the Future By Looking To The Past: Examining Research Published On Organisations And Environment. Organisation \& Environment, 19(4), 458-478.

Chan, E. S. (2008). Barriers to EMS in the Hotel Industry. International Journal of Hospitality Management, 27(2), 187-196.

Daily, B. F., Bishop, J. W., \& Massoud, J. A. (2012). The Role Of Training And Empowerment In Environmental Performance: A Study Of The Mexican Maquiladora Industry. International Journal of Operations \& Production Management, 32(5), 631-647.

Dantes, 2003. Environmental Performance Indicators. 2016, Retrieved http://www.dantes.info/Tools\&Methods/Environmentalinformation/enviro_info_spi_epi.html

de Grosbois, D. (2012). Corporate Social Responsibility Reporting By The Global Hotel Industry: Commitment, Initiatives And Performance. International Journal of Hospitality Management, 31(3), 896-905.

Delmas, M., \& Blass, V. D. (2010). Measuring Corporate Environmental Performance: The Trade- Offs Of Sustainability Ratings. Business Strategy and the Environment, 19(4), 245-260.

Erdogan, N., \& Baris, E. (2007). Environmental Protection Programs And Conservation Practices Of Hotels in Ankara, Turkey. Tourism Management, $28(2), 604-614$.

Fraj, E., Martínez, E., \& Matute, J. (2011). Green Marketing Strategy And The Firm's Performance: The Moderating Role Of Environmental Culture. Journal of Strategic Marketing, 19(4), 339-355.

Gadenne, D. L., Kennedy, J., \& McKeiver, C. (2009). An Empirical Study Of Environmental Awareness And Practices in SMEs. Journal of Business Ethics, 84(1), 45-63.

Graci, S., \& Kuehnel, J. (2011). How to Increase Your Bottom Line By Going Green. Green Hotels \& Responsible Tourism Initiative.

GRI (Global Reporting Initiative) 2002, Sustainability Reporting Guidelines, Global Reporting Initiative, Boston, MA

Hoffman, A. J. (2004). Business Decisions and the Environment: Significance, Challenges, and Momentum of an Emerging Research Field. Decision Making for the Environment: Social and Behavioural Science Research Priorities, (October 2004), 200-229.

Ilinitch, A. Y., Soderstrom, N. S., \& Thomas, T. E. (1998). Measuring Corporate Environmental Performance. Journal of Accounting and Public Policy, 17(4), 383408.

ISO (International Organisation for Standardisation), 1999. ISO 14031:1999 Environmental Management - Environmental Performance Evaluation - Guidelines.

Jabbar, M. H., \& Abid, M. (2014). GHRM: Motivating Employees towards Organisational Environmental Performance. Magnt. Res. Rep., 2, 267-278.

Jabbour, C. J. C., Santos, F. C. A., \& Nagano, M. S. (2008). Environmental Management System And Human Resource Practices: Is There A Link Between Them In Four Brazilian Companies?. Journal of Cleaner Production, 16(17), 1922-1925.

Jermier, J. M. (2008). Exploring Deep Subjectivity In Sociology And Organisational Studies: The Contributions Of William Catton And Riley Dunlap On Paradigm Change. Organisation \& Environment, 21(4), 460-470.

Jiang, R. J., \& Bansal, P. (2003). Seeing the need for ISO 14001. Journal of Management Studies, 40(4), 1047-1067.

Judge, W. Q., \& Douglas, T. J. (1998). Performance Implications Of Incorporating Natural Environmental Issues Into The Strategic Planning Process: An Empirical Assessment. Journal of management Studies, 35(2), 241-262.

Kang, K. H., Lee, S., \& Huh, C. (2010). Impacts of Positive And Negative Corporate Social Responsibility Activities On Company Performance In The Hospitality Industry. International Journal of Hospitality Management, 29(1), 72-82.

Kasim, A. (2004). BESR in the Hotel Sector: A Look At Tourists' Propensity Towards Environmentally And Socially Friendly Hotel Attributes In Pulau Pinang, Malaysia. International Journal of Hospitality \& Tourism Administration, 5(2), 61-83.

Kasim, A. (2009). Managerial Attitudes Towards Environmental Management Among Small And Medium Hotels In Kuala Lumpur. Journal of Sustainable Tourism, 17(6), 709-725.

King, A. A., \& Lenox, M. J. (2000). Industry Self-Regulation Without Sanctions: The Chemical Industry's Responsible Care Program. Academy of Management Journal, 43(4), 698-716 
Lee, J. S., Hsu, L. T., Han, H., \& Kim, Y. (2010). Understanding How Consumers View Green Hotels: How A Hotel's Green Image Can Influence behavioural intentions. Journal of Sustainable Tourism, 18(7), 901-914.

Lober, D. J. (1996). Evaluating the Environmental Performance Of Corporations. Journal of Managerial Issues, 8(2), 184-205.

Mendelson, F., \& Piasecki, B. (1999). The Public Face Of Corporate Environmental Strategy. Piasecki, BW, Fletcher, KA; Mendelson, FJ (1999), Environmental Management And Business Strategy. Leadership Skills for the 21st Century.

Milliman, J., \& Clair, J. (1996). Best Environmental HRM Practices In The US. Greening People: Human Resource And Environmental Management, $49-74$.

Puig, M., Wooldridge, C., \& Darbra, R. M. (2014). Identification and Selection Of Environmental Performance Indicators For Sustainable Port Development. Marine Pollution Bulletin, 81(1), 124-130.

Rao, P., la O' Castillo, O., Intal, P. S., \& Sajid, A. (2006). Environmental Indicators For Small And Medium Enterprises In The Philippines: An Empirical Research. Journal of Cleaner Production, 14(5), 505-515.

Revilla, G., Dodd, T. H., \& Hoover, L. C. (2001). Environmental Tactics Used By Hotel Companies in Mexico. International Journal of Hospitality \& Tourism Administration, 1(3-4), 111-127.

Rodríguez-Antón, J. M., del Mar Alonso-Almeida, M., Celemín, M. S., \& Rubio, L. (2012). Use of Different Sustainability Management Systems In The Hospitality Industry. The Case of Spanish hotels. Journal of Cleaner Production, 22(1), 76-84.

Samdin, Z., Bakori, K. A., \& Hassan, H. (2012). Factors Influencing Environmental Management Practices Among Hotels in Malaysia. International Journal of Social, Behavioural, Educational, Economic, Business and Industrial Engineering, 6(5), 889-892.

Siti-Nabiha, A. K., George, R. A., Wahid, N. A., Amran, A., Abustan, I., \& Mahadi, R. (2011). A Field Survey Of Environmental Initiatives At Selected Resorts in Malaysia. World Applied Sciences Journal, 12(1), 56-63.

Srebotnjak, T. (2007). The Role Of Environmental Statisticians In Environmental Policy: The Case Of Performance Measurement. Environmental Science \& Policy, $10(5), 405-418$.

Subramanian, N., Abdulrahman, M. D., Wu, L., \& Nath, P. (2016). Green Competence Framework: Evidence From China. The International Journal of Human Resource Management, 27(2), 151-172.

Sutantoputra, A. W., Lindorff, M., \& Johnson, E. P. (2012). The Relationship Between Environmental Performance And Environmental Disclosure. Australasian Journal of Environmental Management, 19(1), 51-65

Trumpp, C., Endrikat, J., Zopf, C., \& Guenther, E. (2015). Definition, Conceptualization, And Measurement Of Corporate Environmental Performance: A Critical Examination Of A Multidimensional Construct. Journal of Business Ethics, 126(2), 185-204.

United Nations (UN). United Nations Environmental Programme (UNEP), 1997. Recommendations For A Core Set Of Indicators Of Biological Diversity. United Nations, Montreal.

Williams, B., Onsman, A., \& Brown, T. (2010). Exploratory Factor Analysis: A Five-Step Guide For Novices. Australasian Journal of Paramedicine, 8(3), 990399

Williamson, D., Lynch-Wood, G., \& Ramsay, J. (2006). Drivers of Environmental Behaviour In Manufacturing Smes And The Implications for CSR. Journal of Business Ethics, 67(3), 317-330.

Winn, M. L., \& Angell, L. C. (2000). Towards a Process Model Of Corporate Greening. Organisation Studies, 21(6), $1119-1147$.

Wong, K., Tan, P. S., Ng, Y., \& Fong, C. (2013). The Role of HRM in Enhancing Organisational Performance. Human Resource Management Research, 3(1), 11-15.

Yusof, Z. B., \& Jamaludin, M. (2013). Green Approaches Of Malaysian Green Hotels And Resorts. Procedia-Social and Behavioural Sciences, 85, 421-431.

Yusoff, Y. M., Othman, N. Z., Fernando, Y., Amran, A., Surienty, L., \& Ramayah, T. (2015). Conceptualization of Green Human Resource Management: An Exploratory Study From Malaysian-Based Multinational Companies. International Journal of Business Management \& Economic Research, 6(3), 158166. 